\title{
A Total Merit Selection Index for Ontario Organic Dairy Farmers
}

\author{
P. Rozzi, ${ }^{*}$ F. Miglior, $† \ddagger^{1}$ and K. J. Hand§ \\ *OntarBio, RR5 Guelph, Ontario, Canada, N1H 6J2 \\ †Agriculture and Agri-Food Canada, Dairy and Swine Research and Development Center, Sherbrooke, Quebec, Canada, J1M 1 Z3 \\ ‡Canadian Dairy Network, Guelph, Ontario, Canada, N1G 4T2 \\ §CanWest Dairy Herd Improvement, Guelph, Ontario, Canada, N1K 1E5
}

\section{ABSTRACT}

Organic standards require changes in management practices so that health, fertility, and overall fitness are more important than on conventional dairy farms and require different selection objectives. A survey involving 18 (40\%) Ontario organic dairy farms was carried out to collect data on their production systems, breeding policies, and concerns. Compared with conventional farms, organic farms had lower milk production, lower replacement rate, higher somatic cell count, and a much higher rate of crossbreeding. Actual culling rate was $21 \%$, and the main causes were fertility, mastitis, feet and legs, production, and old age. The major areas of concern expressed by organic dairy farmers were related to grazing traits, fertility, health, and longevity. An organic total merit index was developed based on the subjective scores for traits with a genetic evaluation in Canada. The relative weights of production to fitness traits (28:72) were substantially different from those in the Canadian Lifetime Profit Index (54:46), but similar to those used in conventional indices in Sweden and Denmark and in the Swiss organic index. The overall weight on health traits was 2.5 times higher in the organic index and, among fitness traits, the emphasis was substantially higher for lactation persistency, somatic cell score, and body capacity. Correlations between the organic index and Lifetime Profit Index were 0.88 for all bulls proven in Canada, 0.70 for the top 1,000 , and 0.65 for the top 100 , indicating that a different group of bulls would rank at the top of these 2 indices. When the top 100 bulls for either index were compared, those selected for the organic index were about 0.5 standard deviations lower for all yield traits, but were much better for body capacity and somatic cell score, and 0.25 standard deviations higher for herd life, feet and legs, udder conformation, and lactation persistency. Given the small population size, a separate breeding program for an organic management system

Received July 28, 2006.

Accepted October 16, 2006.

${ }^{1}$ Corresponding author: miglior@cdn.ca is not viable in the foreseeable future. However, the organic index would allow producers to rank proven bulls in accordance with their perceived needs.

Key words: organic farming, survey, total merit index

\section{INTRODUCTION}

According to the Canadian General Standards Board (1999), "the principal goal of organic agriculture is to develop productive enterprises that are sustainable and harmonious with the environment." Organic agriculture requires a more holistic approach than conventional agriculture and must meet specific standards. Such standards can be defined at the national or regional level and are enforced at the farm level by independent inspectors. The standards do not allow the use of chemical fertilizers, pesticides, and antibiotics.

Whereas research in organic dairy production has mostly focused on health, alternative medicine, welfare, and nutrition, there has been little research in the area of genetic selection. On a national basis, conventional dairy breeding has followed a philosophy of "one size fits all," with the Holsteinization of dairy production worldwide and the pursuit of the same goal of maximum production per cow per year. More recently, however, there are signs of a change in emphasis with the inclusion of an increasing number of functional traits in the national breeding goals (Miglior et al., 2005). Also, international genetic evaluations have followed this trend and now include production, type, udder health, longevity, and calving performance traits (Mark, 2004; Interbull, 2006), and research is under way for other functional traits, especially female fertility traits (Jorjani, 2005).

Gamborg and Sandøe (2005) reviewed the difficulties of agreeing on a definition of sustainable animal breeding, in spite of the work carried out by the Sustainable European Farm Animal Breeding and Reproduction project. They concluded that a pragmatic definition should be used based on concerns (e.g., animal welfare) addressed by criteria or the direction of change (e.g., improve animal welfare) and measured by appropriate indicators. Boelling et al. (2003) discussed organic animal breeding and listed genetic diversity, genotype-by- 
environment interaction $(\mathbf{G} \times \mathbf{E})$, and selection goals as the main areas of research.

Genotype-by-environment interaction between conventional and organic production should be estimated because, if significant, it would decrease the effectiveness of using breeding values estimated in conventional herds (Nauta, 2001; Pryce et al., 2001). Nauta et al. (2006b), from an analysis of 188 organic and 152 conventional Dutch dairy farms, found genetic correlations significantly lower than unity between organic and conventional farms: 0.80 for milk $(P<0.01)$ and 0.78 for protein yield $(P<0.05)$. However, the standard error of the estimates was still too large to conclude that a separate organic breeding program was necessary.

In general, estimating $\mathrm{G} \times \mathrm{E}$ between organic and conventional herds can be problematic because of the small size of many organic populations and the heterogeneity among organic farms within and across countries. Therefore, results from a given population or region cannot be generalized. For example, in Switzerland and Denmark, organic farms are very similar for herd size and feeding to conventional farms (B. Bapst, FiBL, Research Institute of Organic Agriculture, Frick, Switzerland; personal communication; Kristensen and Pedersen, 2001), whereas in the Netherlands and Great Britain there are large differences among organic dairy farms (Nauta, 2001; Pryce et al., 2001). A reliable estimate of $\mathrm{G} \times \mathrm{E}$ is presently unfeasible in Ontario because of the small organic population involved. Boettcher et al. (2003) studied the effects of different feeding systems on Canadian genetic evaluations and found no significant $\mathrm{G} \times \mathrm{E}$ between pasture-based and conventional herds in Ontario and Nova Scotia. If the main differences between conventional and organic herds were only due to pasture availability, then little or no $\mathrm{G} \times \mathrm{E}$ interaction would be expected. However, this may not be the case because organic requirements also affect other aspects of dairy production.

The choice of the breeds best suited for organic production is a subject of much discussion. Sustainable animal production should adjust to local conditions and it may require different types of animals to fit different production situations. Therefore, genetic diversity, choice of breed, and mating system are important for organic dairy breeding. Organic production tends to increase the amount of forage in the ration and to require feeding on pasture. Research in Ireland (Dillon et al., 2003a,b) and in New Zealand (Lopez-Villalobos et al., 2000; Harris and Kolver, 2001) has shown that under a grazing system, Holstein cows of high genetic potential might have more reproductive problems and lower lifetime performance than other breeds or crosses. Concerns about loss of biodiversity and of robustness due to the conventional selection programs have prompted parts of the organic sector to try to conserve genetic resources, such as local or traditional breeds. In Germany, at the organic research station in Frankenhausen, a herd of traditional Friesian cows is maintained, and organic farmers in the Netherlands use Blaarkop and conventional Friesian cows (Nauta, 2001).

Olesen et al. (2000) discussed the definition of animal breeding goals for sustainable systems and showed how animal breeding should contribute to optimize the whole production system. Therefore, different characteristics of agricultural production will affect selection goals. For example, when high energy and nutrition costs force production onto marginal land, then selection should aim to improve utilization of local feeds and to increase intake of roughage and adaptation to lowenergy-input systems. When production must adapt to diverse local conditions, selection should increase livestock robustness and adaptation to different environments. When chemical medications are less available or too costly, selection should improve genetic resistance to disease and parasites. Therefore, the focus may shift on different groups of traits, depending on production characteristics and constraints. Then, these different conditions could apply to organic production and affect selection goals. Total merit indices specific for organic dairy farmers are currently available in a few countries: in Switzerland (Bapst, 2001) and, for dualpurpose populations, in the Bavarian region of Germany (Krogmeier, 2003) and in Austria (Baumung et al., 2001).

The objectives of this study were to identify the priorities of selection for organic dairy production in Ontario and to formulate a total merit index for organic dairy farmers based on their subjective priorities. Given the limits imposed by the small size of the organic dairy population, the use of the index was not to formulate an alternative selection program, but to select among proven bulls those with the highest breeding values for the chosen traits.

\section{MATERIALS AND METHODS}

Organic dairy production in Ontario started with the first farm in 1978. It developed quite slowly at first, but has been growing at a fast rate in recent years. In 1999, there were 20 certified organic dairy farms; by 2004 there were 46 ; and the number is expected to double again within the next $2 \mathrm{yr}$. This growth is striking because it occurred during a period of losses of income in the overall agricultural sector in Canada. In 2004, organic milk in Ontario was $0.5 \%$ of the total milk produced in the province and was produced by $0.9 \%$ of the farms. However, demand for organic dairy 
products is larger than supply and further growth is expected.

A short survey of 20 farms was first carried out to identify breeds and mating plans most commonly used in organic herds. A more extensive questionnaire was then developed to identify production characteristics and breeding strategies of organic dairy farms in Ontario. Because the majority of Ontario organic farms participate in milk recording (DHI), DHI records were also used for the study.

For this research a sample representative of organic dairy farms in Ontario was identified. The sample included 18 farms, or $40 \%$, out of a total 46 organic Ontario farms. These farms were spread over the main agricultural regions of the province and had different breeds, breeding strategies, and different levels of milk production. All farms were certified organic between 1978 and 2002, except for 1 farm still in transition. Response rate was $100 \%$. The same researcher visited all 18 farms and conducted individual interviews, and all producers except one agreed to release their DHI data for research purposes. Information on production, crops, feeding, culling, health problems, and breeding policies based on the last year were collected through the survey. Producers in the survey were asked to score different factors affecting their management. Scores ranged from 0 (not important) to 5 (most important) and answers were averaged across farmers to determine the relative weight for each trait. Differences in average scores were tested with Friedman's multiple comparison test (Hollander and Wolfe, 1973). Six years of complete DHI data were included, from 1998 to 2003. All participating herds were enrolled in DHI services over this period, except for 1 that had 4 instead of $6 \mathrm{yr}$ of data.

An alternative approach based on the declared preferences of organic farmers, rather than economic weights, was taken to build a total merit index for organic dairy producers in Ontario. Such an index was intended as a tool to select from available proven bulls that best met the perceived needs of organic producers. Farmers were asked to choose and score which traits to select. A total merit index was formulated as follows:

$$
\mathrm{H}_{\mathrm{i}}=\mathrm{v}_{1} \mathrm{~A}_{1 \mathrm{i}}+\mathrm{v}_{2} \mathrm{~A}_{2 \mathrm{i}}+\ldots \mathrm{v}_{\mathrm{m}} \mathrm{A}_{\mathrm{mi}}
$$

where $H_{i}=$ total merit index for ith bull, $\mathrm{v}_{1}=$ relative subjective weight for trait 1 , and $\mathrm{A}_{1 \mathrm{i}}=\mathrm{EBV}$ of ith bull for trait 1.

Average EBV of bulls selected by the various indices and correlations between indices were used to compare the organic total merit index with the conventional index-the Lifetime Profit Index (LPI), which is the selection index for all dairy breeds in Canada (Canadian Dairy Network, 2005).

\section{RESULTS AND DISCUSSION}

\section{Organic Dairy Production in Ontario}

Milk Production. Based on 6 yr of official milk records from 1998 to 2003 , the average 305 -d milk production for the 18 organic herds was $8,069 \mathrm{~kg}$, standardized to a mature equivalent, with $3.93 \%$ fat and $3.23 \%$ protein and a yield of $317 \mathrm{~kg}$ of fat and $260 \mathrm{~kg}$ of protein. Compared with conventional Ontario farms enrolled in DHI in the same years, organic farms had lower production for milk yield (-19\%) but higher fat $(+0.28 \%)$ and protein percentage $(+0.04 \%$; CanWest DHI, 2003). The lower milk production was likely due to a less intensive management rather than a breed effect, because $89 \%$ of all cows were pure Holstein. The higher fat percentage in organic milk was probably due to the high content of forage in the ration. The average SCC, at 309,000 cell $\mathrm{s} / \mathrm{mL}$, was about 50,000 cells $/ \mathrm{mL}$ higher than in conventional Ontario farms. Overall, average herd size of 45 cows in organic farms was lower than the average conventional herd at 56 cows (CanWest DHI, 2003). Across herds there was a negative correlation $(-0.56)$ between milk production and SCC. When herds were split into 3 production levels, higher producing herds had a more intensive management, had become organic more recently, and had lower SCC. However, the number of organic herds was too small to make any significant inference when split in 3 production levels.

Among the factors limiting milk production, organic farmers in Ontario felt that the milk quota was by far the most important, with an average score of 4.2 (5 being the maximum score). Barn size, labor, and grain and forage production were all scored around 2.5 and were considered very limiting by few farmers (Table 1). Differences between average scores were significant only between milk quota and all other factors $(P<0.05)$. Even though organic agriculture tends to be more labor intensive than conventional, only 2 producers saw labor as a serious constraint for milk production.

Several studies have compared organic and conventional dairy herds. A survey of organic dairy farms in 12 European countries has shown that in most countries, milk yield per cow tended to be lower (5 to 25\%) in organic than conventional farms (Offermann and Nieberg, 2000). Only in 3 participating countries was organic production slightly higher than in conventional farms. Nauta et al. (2006a) analyzed the differences between organic and conventional dairy production and the effects of transition years on various traits. Their research, based on data from 367 organic and 966 conventional herds, found significant decreases in milk $(P$ $<0.001)$ and protein percentage $(P<0.05)$ and an increase in SCC $(P<0.01)$, all resulting from the shift to 
Table 1. Main factors limiting milk production: average score $(0=$ not important, $5=$ most important $)$ and number of farms scoring it as the most important ${ }^{1}$

\begin{tabular}{lccccc}
\hline & \multicolumn{5}{c}{ Constraint } \\
\cline { 2 - 6 } Score & $\begin{array}{c}\text { Milk } \\
\text { quota }\end{array}$ & $\begin{array}{c}\text { Barn } \\
\text { size }\end{array}$ & Labor & $\begin{array}{c}\text { Forage } \\
\text { production }\end{array}$ & $\begin{array}{c}\text { Grain } \\
\text { production }\end{array}$ \\
\hline Average score & $4.2^{\mathrm{a}}$ & $2.6^{\mathrm{b}}$ & $2.3^{\mathrm{b}}$ & $2.4^{\mathrm{b}}$ & $2.3^{\mathrm{b}}$ \\
Median score & 5.0 & 2.5 & 2.0 & 2.0 & 2.0 \\
No. of farms with score $=5$ & 12 & 4 & 2 & 2 & 1 \\
\hline
\end{tabular}

${ }^{\mathrm{a}, \mathrm{b}}$ Means within rows without a common letter are significantly different $(P<0.05)$.

${ }^{1}$ Friedman's multiple comparison test was used for multiple pairwise comparisons of means.

organic production. In a study of 31 Norwegian organic dairy herds, the overall mean SCC was higher $(P=$ $0.016)$ than in 93 conventional herds but it was lower for first- and second-lactation cows $(P=0.007)$ and higher above sixth lactation $(P=0.0015$; Hardeng and Edge, 2001). This was not the case in a study of 82 organic Danish farms grouped by conversion year (before 1990, 1995, 1999 to 2000), where herds converted before 1990 had significantly lower milk production $(P<0.05)$ and lower bulk SCC $(P<0.05)$ than all other organic and conventional herds. Milk production in herds that converted in 1995 was higher than in conventional before conversion, but became significantly lower $(P<0.05)$ after conversion (Bennedsgaard et al., 2003). In the same study, there was no difference in herd size between organic and conventional. Thus, differences between organic and conventional dairy production varied from country to country and specific patterns cannot be identified.

Crops and Feeding. Tillable land was on average 101 ha per farm, ranging from 36 to 243 ha, with hay, haylage, and pasture on $68 \%$ of the land (Table 2 ). Small grains and forage were grown on average on $88 \%$ of the land and corn on $7 \%$ of the land. Only $28 \%$ of surveyed farms grew soybeans and $61 \%$ grew corn. Corn was less common in organic rotations because it needed more nutrients and was more prone to weed infestation. Also, due to the widespread use in Canada of genetically modified varieties, it was difficult for organic farms to find required genetically modified-free corn and soybean seeds on the market. Compared with a sample of 169 conventional Ontario farms, pasture, hay, and haylage were higher in organic: $68 \%$ instead of $55 \%$ of tillable land, whereas corn was lower: $7 \%$ instead of 14\% (OMAFRA, 2003).

Culling and Health. A measure of annual replacement rate was given by the DHI data and referred to all cows leaving the herd, including cows culled as well as sold for dairy. This overall replacement rate was $28 \%$ for organic farms, lower than the provincial average (32\%) for all herds in DHI. Thus, cows tended to last longer in organic than in conventional herds, which could be the effect of a lower production pressure in these herds. Furthermore, when farmers were asked how many cows were culled in 2003 , the reported culling rate was $21 \%$.

When reasons for culling were scored, the most important were fertility and mastitis, followed by feet and legs. Milk production and old age were secondary, whereas overall conformation, calving problems, injuries, or temperament received a very low score (Table $3)$. Average scores for fertility and mastitis were significantly higher than for all other reasons for culling $(P<0.05)$, except for feet and legs. Except for fertility, culling reasons seemed to differ between organic and conventional herds. In conventional Ontario herds, fertility was the main reason for culling, followed by low production, mastitis, sickness, udder breakdown, and feet problems (CanWest DHI, 2003).

Health was expected to be an important area of concern because, under Ontario organic regulations, the use of antibiotics and other drugs leads to the loss of

Table 2. Tillable land and major crops in organic farms

\begin{tabular}{lccccccccc}
\hline & & \multicolumn{2}{c}{ Land/cow (ha) } & & \multicolumn{3}{c}{ Crops (\% of tillable land) } \\
\cline { 3 - 4 } & $\begin{array}{c}\text { Tillable } \\
\text { land (ha) }\end{array}$ & Tillable & $\begin{array}{c}\text { Pasture } \\
\text { and hay }\end{array}$ & & $\begin{array}{c}\text { Pasture } \\
\text { and hay }\end{array}$ & Corn & Soybean & $\begin{array}{c}\text { Mixed } \\
\text { grains }\end{array}$ \\
\hline Average & 101 & 2.2 & 1.5 & & 68 & 7 & 4 & 20 \\
SD & 51.3 & 0.95 & 0.76 & & 17.8 & 6.9 & 7.0 & 9.3 \\
Median & 85 & 2.1 & 1.5 & & 69 & 8 & 0 & 23 \\
Minimum & 36 & 1.0 & 0.5 & & 30 & 0 & 0 & 0 \\
Maximum & 243 & 4.5 & 3.8 & & 100 & 19 & 24 & 33 \\
\hline
\end{tabular}


Table 3. Average subjective score for culling reasons $(0=\text { not important, } 5=\text { most important })^{1}$

\begin{tabular}{lcccccccc}
\hline & Fertility & $\begin{array}{c}\text { Mastitis } \\
\text { and SCC }\end{array}$ & $\begin{array}{c}\text { Feet } \\
\text { and legs }\end{array}$ & Milk & Age & $\begin{array}{c}\text { Overall } \\
\text { conformation }\end{array}$ & $\begin{array}{c}\text { Calving } \\
\text { Injuries }\end{array}$ & $\begin{array}{c}\text { Milking } \\
\text { problems }\end{array}$ \\
temperament
\end{tabular}

${ }^{\mathrm{a}-\mathrm{c}}$ Means within a row without a common letter are significantly different $(P<0.05)$.

${ }^{1}$ Friedmans's multiple comparison test was used for multiple pairwise comparisons of means.

the organic status of an animal. From the questionnaire, the most common health problems as percentage of animals affected were mastitis and feet and legs at about $6 \%$, whereas calving difficulty, milk fever, and ketosis were at about $3 \%$ (Table 4). Mastitis and calving problems were the most widespread across farms, affecting $11(60 \%)$ of surveyed farms. Milk fever and ketosis did not occur in half of the farms and together affected $2 \%$ of all cows. All interviewed farmers recognized that after becoming organic, the incidence of health problems, particularly regarding metabolic disorders, had definitely decreased and that cases of acute mastitis had almost disappeared.

According to the results of the survey, a veterinarian visited an organic farm an average of only 3 to 4 times per year for health reasons, and $6 \%$ of all the cows in the sample were visited in a year, mostly for a difficult calving. Previous research in Ontario showed that veterinary costs, inclusive of breeding, were $20 \%$ lower in organic than in conventional farms (Stonehouse et al., 2001). However, low reliance on veterinarians could also be due to the lack of veterinarians trained in homeopathic medicine. Hardeng and Edge (2001) found that mastitis, ketosis, and milk fever cases had lower incidence rates in 31 organic herds compared with 93 conventional herds in Norway. In Denmark, fewer mastitis treatments were reported in the old organic herds (Bennedsgaard et al., 2003).

\section{Organic Dairy Breeding in Ontario}

Breeds and AI Usage. The Holstein breed was prevalent among the 18 surveyed farms, except for 2 farms: 1 with Jersey and 1 with Brown Swiss cows. The general feeling among the organic farmers was that Holstein cows have been selected for a different system of produc- tion and had problems adapting to a forage-based diet. There were also concerns about their health, fertility, longevity, grazing ability, loss of body condition, general fitness, and inbreeding. Research has shown that some of these concerns may be justified. Studies in New Zealand (Harris and Kolver, 2001) and in Ireland (Dillon et al., 2003a,b), where dairy production is based on pasture, have indicated that the most profitable cows for these environments were different from those selected under a high-concentrate regimen. Other researchers (Weigel et al., 2001; Kearney et al., 2004) have indicated a possible $\mathrm{G} \times \mathrm{E}$ interaction for milk production under intensive and extensive production systems. Kearney et al. (2004) have suggested that genetic correlations could be affected by a scaling effect between environments, whereas within environment, significant differences existed for milk and protein genetic correlations between the upper and lower grazing quartiles.

Crossbreeding can be very effective in eliminating inbreeding and improving fitness traits through hybrid vigor and decreased homozygosity. However, the choice of breed or breeds is critical, and there is little information available for dairy crossbreeding with respect to specific and general combining ability. Furthermore, the choice of bulls within breed is as important as the choice of the breeds, and it requires a good knowledge of the actual breeding values for each breed. In the organic sector, there is often the idea that going back to the "good, old breeds" is the approach to take, but some of these minor breeds may not have a developed selection program. Thus, the farmer is the one doing the progeny testing on his own herd, with all the risks involved.

Crossbreeding was more frequent in organic than in conventional herds. In fact, about 7, or $40 \%$, of the 18

Table 4. Average cows (\%) and number of herds affected by different health problems

\begin{tabular}{|c|c|c|c|c|c|c|c|}
\hline & $\begin{array}{l}\text { Clinical } \\
\text { mastitis }\end{array}$ & $\begin{array}{c}\text { Feet } \\
\text { and legs }\end{array}$ & $\begin{array}{l}\text { Calving } \\
\text { problems }\end{array}$ & $\begin{array}{l}\text { Milk fever } \\
\text { and ketosis }\end{array}$ & $\begin{array}{l}\text { Injury and } \\
\text { sickness }\end{array}$ & $\begin{array}{c}\text { Metritis } \\
\text { and retained } \\
\text { placenta }\end{array}$ & $\begin{array}{l}\text { Bloat and } \\
\text { displaced } \\
\text { abomasum }\end{array}$ \\
\hline Cows affected within herd (\%) & 6.5 & 6.3 & 3.5 & 2.9 & 1.1 & 0.5 & 0.5 \\
\hline No. of herds affected & $11 / 18$ & $7 / 18$ & $10 / 18$ & $9 / 18$ & $7 / 18$ & $3 / 18$ & $4 / 18$ \\
\hline
\end{tabular}


Table 5. Number of crossbred cows and number of herds by breed combination ${ }^{1}$

\begin{tabular}{lccccccc}
\hline & \multicolumn{7}{c}{ Breed composition } \\
\cline { 2 - 8 } & $\mathrm{HO} \times \mathrm{BS} \times \mathrm{JE}$ & $\mathrm{HO} \times \mathrm{DB}$ & $\mathrm{HO} \times \mathrm{MS}$ & $\mathrm{HO} \times \mathrm{BS}$ & $\mathrm{HO} \times \mathrm{SI}$ & $\mathrm{HO} \times \mathrm{AY}$ & $\mathrm{HO} \times \mathrm{JE}$ \\
\hline No. of cows & 44 & 28 & 13 & 5 & 6 & 2 & 1 \\
No. of herds & 1 & 3 & 1 & 2 & 1 & 1 & 1 \\
\hline
\end{tabular}

${ }^{1}$ Breed cross combinations include all crosses present for respective breeds indicated: $\mathrm{HO}=$ Holstein, $\mathrm{BS}=$ Brown Swiss, JE = Jersey, DB = Dutch Belted, MS = Milking Shorthorn, SI = Simmental, and AY = Ayrshire.

farmers in this research had crossbred some or all of their cows, whereas 9 had pure Holstein, 1 had pure Jersey, and 1 had pure Brown Swiss cows. Only 2 herds opted for crossbreeding all their cows, whereas in the other 5 herds, $17 \%$ of the cows were crossbred. The most frequent crosses were 3 -way rotational crosses with Holstein, Brown Swiss, and Jersey (all in 1 herd), followed by crosses between Holstein and Dutch Belted, Milking Shorthorn, Simmental, Brown Swiss, Ayrshire, or Jersey (Table 5).

There was a positive correlation $(0.49)$ between AI usage and production level across herds, such that AI usage went from $100 \%$ in the high-producing herds to $59 \%$ in the low herds (Table 6). Using natural service sires was also necessary when crossing with minor breeds because semen from these breeds was rarely available from AI centers, and this could have a negative impact on the herds' genetic progress. There was also an association between percentage of Holstein in the herd and milk production level. The higher producing herds were pure Holstein, with average milk production of $9,492 \mathrm{~kg}$, whereas crossbred herds had lower average production $8,094 \mathrm{~kg}$ for herds with $9 \%$ of crossbred cows and $6,928 \mathrm{~kg}$ for herds of $43 \%$ of crossbred cows. However, fat and protein content were not affected by crossbreeding (Table 6).

Traits to be Selected. When organic farmers were asked to list the major areas of concern that should be addressed by selection, they mentioned grazing traits $(39 \%)$, fertility (28\%), health (22\%), and longevity (22\%). Only 3 out of the 18 farmers mentioned milk, and only 1 farmer mentioned fat and protein content.
Many farmers felt that the present level of production was high enough, for some even too high, and they would have liked more attention to be paid to functional traits, particularly to grazing traits, to increase the cow's genetic ability to produce on grass alone without adverse effects on fertility and health in general.

Organic farmers were asked to score which traits, among those with a genetic evaluation in 2003-2004, were the most important for selection on their farm. Based on their average score, functional traits came first, with feet and legs and overall udder, followed by fat yield, body capacity, protein yield, and SCS (Table 7). The average scores for feet and legs and overall udder were significantly higher than those of lactation persistency, calving ease, and milk. Body capacity scores were high because more capacity was associated with higher forage intake, and similar to those of fat and protein yield. Somatic cell score, as an indicator of udder health and mastitis resistance and longevity, had similar scores. Milk production was the least important trait, with only 2 farmers scoring it as the most important, and 12 ignoring it. Only 2 farmers used the LPI extensively, and its average score was only 2.28. Dairy cattle selection is quite homogeneous in conventional herds in Canada, as dairy farmers and AI organizations in Canada use the LPI index extensively for their selection decisions. Chesnais and Van Doormaal (2006) have compared genetic level and progress of Holstein, Ayrshire, and Jersey cows for a series of traits including LPI from 1983 to 2003. They concluded that LPI had the highest genetic trend (2.89 genetic SD unit in Holstein) among all traits considered. In a separate

Table 6. Artificial insemination usage, fat and protein percentages, breeds and crossbreeding by herd production level

\begin{tabular}{|c|c|c|c|c|c|c|c|}
\hline \multirow[b]{2}{*}{$\begin{array}{l}\text { Milk production } \\
(\mathrm{MP})^{1}\end{array}$} & \multicolumn{3}{|c|}{$\begin{array}{l}\text { All herds } \\
(\mathrm{n}=18)\end{array}$} & \multicolumn{4}{|c|}{$\begin{array}{l}\text { Herds that include Holstein genetics } \\
\qquad(\mathrm{n}=16)\end{array}$} \\
\hline & $\begin{array}{l}\mathrm{AI} \text { on } \\
\text { cows }(\%)\end{array}$ & Fat $\%$ & Protein \% & $\begin{array}{l}\text { Holstein } \\
\text { cows }(\%)\end{array}$ & Fat $\%$ & Protein $\%$ & $\begin{array}{l}\text { Crossbred } \\
\text { cows }(\%)\end{array}$ \\
\hline$>8,700$ & 100 & 3.85 & 3.25 & 100 & 3.85 & 3.25 & 0 \\
\hline $7,500<\mathrm{MP}>8,700$ & 76 & 3.97 & 3.19 & 91 & 3.84 & 3.13 & 9 \\
\hline$<7,500$ & 59 & 3.94 & 3.27 & 57 & 3.89 & 3.21 & 43 \\
\hline
\end{tabular}

${ }^{1}$ Milk production (kg), based on cows' 305-d mature equivalent production. 
Table 7. Average score of traits selected by 18 organic farmers $(0=$ not important, $5=$ most important $)$

\begin{tabular}{|c|c|c|c|c|c|c|c|c|c|c|}
\hline & \multicolumn{7}{|c|}{ Functional traits } & \multirow{2}{*}{\multicolumn{3}{|c|}{ Production traits $(\mathrm{kg})$}} \\
\hline & \multirow{2}{*}{$\begin{array}{c}\text { Feet } \\
\text { and legs }\end{array}$} & \multirow{2}{*}{$\begin{array}{l}\text { Overall } \\
\text { udder }\end{array}$} & \multirow{2}{*}{$\begin{array}{l}\text { Body } \\
\text { capacity }\end{array}$} & \multirow[b]{2}{*}{ SCS } & \multirow[b]{2}{*}{ Longevity } & \multirow{2}{*}{$\begin{array}{l}\text { Calving } \\
\text { ease }\end{array}$} & \multirow{2}{*}{$\begin{array}{l}\text { Lactation } \\
\text { persistency }\end{array}$} & & & \\
\hline & & & & & & & & Fat & Protein & Milk \\
\hline Median score & 5.00 & 4.50 & 3.00 & 3.00 & 2.00 & 1.50 & 1.00 & 3.50 & 3.50 & 1.00 \\
\hline No. of farms with score $=5$ & 10 & 9 & 7 & 2 & 4 & 4 & 3 & 6 & 6 & 2 \\
\hline
\end{tabular}

${ }^{\mathrm{a}, \mathrm{b}}$ Means within a row without a common letter are significantly different $(P<0.05)$.

${ }^{1}$ Friedmans's multiple comparison test was used for multiple pairwise comparisons of means.

analysis by Canadian Dairy Network (2003), Canadian provinces were compared by the average LPI of the cows, and Ontario was found to have the highest average LPI among all provinces.

In Switzerland, a survey was carried out in 2003: out of 3,595 Swiss organic dairy farmers, 1,000 were sampled and 608 responded to a questionnaire focused on breeding decisions and problems (Haas and Bapst, 2004). For these farmers, the most important traits were the following: fertility (84\%), SCC (81\%), longevity (78\%), milk performance from forage $(77 \%)$, and protein and fat content (72\%). Also, Swiss organic farms focused on functional traits, and grazing-related traits were very important for them as well.

Organic Total Merit Index. The organic total merit index was built based on the traits chosen by organic farmers and their relative subjective scores (Table 7). At the time of the survey, calving ease was chosen as a fertility trait because genetic evaluations for fertility were not available. However, when the organic selection index was put together, bull proofs for daughters' fertility had become available in Canada. Calving ease was replaced by fertility because this was actually the trait that farmers wanted to improve if available, and because calving ease should be used to avoid problems rather than being selected for directly.

Subjective scores were averaged across respondents, and the relative weights transformed to a percentage scale (Table 8). Feet and legs, overall udder, body capacity, and SCS were the most important functional traits for Ontario organic farmers and together they had almost the same weight as all the other traits, production included. One of the major features of this index was the low weight of the production traits relative to functional: 28 to $72 \%$. Even though there is a definite tendency toward increasing the relative importance of functional traits, worldwide emphasis on production traits in the Holstein breed ranges from 29 to $80 \%$, with most countries placing at least $50 \%$ emphasis on production. Only those used in Scandinavian countries have a relative weight on production around $30 \%$, very close to that of the organic index. Within production traits, protein is by far the most important trait, with a 3 to 1 ratio relative to fat, and milk is ignored in almost half of the countries (VanRaden, 2004; Miglior et al., 2005). This was in contrast with the weights in the organic index, where fat had a slightly higher emphasis than protein yield. Worldwide, the most important functional traits included in Holstein selection indices were, in decreasing order, longevity, SCS, overall udder, feet and legs, fertility, overall conformation, calving ease, growth, and milking temperament (Miglior et al., 2005). The group of traits considered in the different selection indices varied noticeably between countries. Only longevity was included in all indices, followed by udder traits, SCS, and feet and legs.

Even though the organic index was based on farmers' preferences, the relative weights of production to functional traits were quite similar to those used in Sweden and Denmark (Miglior et al., 2005). Among functional traits, longevity had similar weights in the organic and in the Scandinavian indices. Udder health and fertility were more important in Scandinavian countries than in the organic index (22.5 vs. $18 \%$, respectively), whereas feet and legs and overall udder were more important in the organic index than in Scandinavian countries ( 28 vs. $18 \%$, respectively). Another difference

Table 8. Weights (\%) of standardized traits included in different total merit indices

\begin{tabular}{llcc}
\hline Trait group & \multicolumn{1}{c}{ Trait } & $\begin{array}{c}\text { Organic total } \\
\text { merit index }\end{array}$ & LPI $2005^{1}$ \\
\hline Production & Milk yield (kg) & 5.0 & 0.0 \\
& Fat yield (kg) & 12.0 & 20.5 \\
& Protein yield (kg) & 11.0 & 31.0 \\
& Fat percentage & 0.0 & 1.0 \\
& Protein percentage & 0.0 & 1.5 \\
Durability & Herd life & 8.0 & 7.0 \\
& Feet and legs & 14.0 & 11.0 \\
& Body capacity & 11.0 & 4.0 \\
Health & Overall udder & 14.0 & 14.0 \\
& SCS & 9.0 & 3.0 \\
& Lactation persistency & 8.0 & 0.0 \\
& Fertility & 8.0 & 5.0 \\
& Milking speed & 0.0 & 0.5 \\
& Udder depth & 0.0 & 1.5 \\
\hline
\end{tabular}

${ }^{1}$ LPI = Lifetime Profit Index, the official total merit index for Canada in 2005 (Canadian Dairy Network, 2005). 
Table 9. Correlations between the organic total merit index and LPI ${ }^{1}$ based on Canadian official evaluations from May 2005

\begin{tabular}{lc}
\hline Bulls & Index correlations \\
\hline All 1,000 & 0.88 \\
Top & 0.70 \\
Top 100 & 0.65 \\
Top 50 & 0.64 \\
\hline
\end{tabular}

${ }^{1}$ LPI = Lifetime Profit Index, the official total merit index for Canada in 2005 (Canadian Dairy Network, 2005).

was the weight given by organic producers to body capacity $(11 \%)$ and lactation persistency $(8 \%)$ to increase forage ingestion and minimize peaks in the lactation curve.

Ontario Organic Total Merit Index vs. Canadian LPI. National genetic evaluations from May 2005 provided by Canadian Dairy Network were used to calculate the organic index using the weights from Table 8. Compared with the Canadian official selection index, LPI, the major difference was in the relative emphasis on production: $54 \%$ in the LPI compared with $28 \%$ in the organic index. On the other hand, when functional traits were grouped as durability and health related traits, health traits were 2.5 times more important in the organic index, whereas emphasis on durability traits was more similar. Correlations were estimated for all bulls officially proven in May 2005, and overall correlation between the 2 indices was 0.88 . However, it decreased to 0.70 for the top 1,000 bulls for the organic index and to 0.65 for the top 100 bulls (Table 9).

When average EBV of the top 100 bulls for these 2 indices were compared (Table 10), bulls selected for the organic index were about $0.5 \mathrm{SD}$ lower for all yield traits, higher for body capacity, and lower for SCS. Those bulls were also about $0.25 \mathrm{SD}$ better for herd life,

Table 10. Average EBV of top 100 bulls for $\mathrm{LPI}^{1}$ and organic total merit index and their difference in SD units

\begin{tabular}{lccc}
\hline & LPI & Organic & $\begin{array}{c}\text { Organic - LPI } \\
\text { (SD) }\end{array}$ \\
\hline Milk kg & 1,301 & 917 & -0.46 \\
Fat kg & 53 & 37 & -0.52 \\
Protein kg & 46 & 31 & -0.60 \\
Fat percentage & 0.08 & 0.05 & -0.07 \\
Protein percentage & 0.03 & 0.01 & -0.16 \\
Herd life & 3.14 & 3.17 & 0.26 \\
Feet and legs & 4.6 & 6.0 & 0.27 \\
Frame/capacity & 1.7 & 4.8 & 0.61 \\
Mammary system & 7.8 & 9.1 & 0.25 \\
Calving ease & 86.9 & 86.2 & -0.14 \\
SCS & 2.91 & 2.80 & -0.47 \\
Lactation persistency & 68.1 & 68.8 & 0.25 \\
Daughters' fertility & 67.0 & 66.9 & -0.03 \\
\hline
\end{tabular}

${ }^{1}$ LPI = Lifetime Profit Index, the official total merit index for Canada in 2005 (Canadian Dairy Network, 2005). feet and legs, mammary system, and lactation persistency, and about 0.15 SD lower for protein percentage and calving ease. Thus, by selecting proven bulls with the best organic index, organic producers could improve health traits and durability at the expense of production. However, even though this index was based on producers' preferences, its use would depend on it being available to organic producers on a regular basis.

Organic Total Merit Indices Worldwide. Total merit indices for organic dairy producers have been developed in Switzerland for the 3 main breeds of Brown Swiss, Simmental, and Holstein (Bapst, 2001), and were widely used by organic Brown Swiss producers (B. Bapst, FiBL, Research Institute of Organic Agriculture, Frick, Switzerland; personal communication). The Brown Swiss index had 24\% emphasis on production traits, very similar to that of the Ontario organic index. Among functional traits, the Swiss index put more emphasis on lactation persistency and longevity, and less on body capacity and feet and legs than the Ontario index.

Organic selection indices have also been developed in the Bavaria region of Germany for the Simmental, Brown Swiss, and Gelbvieh breeds (Krogmeier, 2003) and in Austria for the Simmental (Baumung et al., 2001). All of these breeds have a beef component in their selection indices, either conventional or organic, with a weight of 10 to $15 \%$ in Bavaria and 13 to $19 \%$ in Austria. In Bavaria, among the functional traits, the most important were fertility (25\%), longevity (15\%), and lactation persistency (10\%), whereas SCS accounted for only $5 \%$. Such indices have been used as models for the Swiss organic indices (Bapst, 2001). Baumung et al. (2001) used a herd simulation approach and showed that changes in returns and costs slightly affected the weights in the organic selection index. Therefore, the organic indices were quite robust to different market scenarios. Only when the value of functional traits was arbitrarily increased by 50 and $100 \%$ did the weights change markedly. This could also suggest that an organic selection index could fit a wide range of farming systems.

\section{CONCLUSIONS}

An organic total merit selection index was developed based on subjective scores expressed by 18 (40\%) of Ontario organic producers, a representative sample of the whole organic sector. Subjective scores of organic producers in Ontario emphasized functional traits, while giving a lower importance to production traits. The overall weight of functional traits was $72 \%$ and the emphasis on production was $28 \%$. Even though the organic index was based on subjective scores, these 
weights were very similar to indices used in conventional farms in Sweden and Denmark and to organic indices used in Switzerland.

Given the limited size of the organic dairy population in Ontario, an alternative selection program would not be viable. However, sires of organic cows could be ranked on a total merit index based on the preferences expressed by organic producers. Such an index was intended as a first step in addressing the needs of dairy organic producers; its limits are due to the fact that sires would be chosen from an existing population selected on a different index (LPI). The use of such index would have a very small effect on the overall genetic progress because it would affect the sire of cow path for $1 \%$ of the cow population.

In Canada the major difference between the Ontario organic index and the LPI index was the relative emphasis between functional and production traits. Among functional traits, body capacity, SCS, and lactation persistency had more emphasis in the organic index. Correlations between these 2 indices were 0.88 for all proven bulls and decreased to 0.65 for the top 100 , indicating that a different group of bulls would rank at the top. However, given the current trend of conventional selection indices toward increasing the emphasis on functional and health traits, differences between conventional and organic indices could be reduced in the future.

Organic farmers surveyed in Ontario and in Switzerland expressed their need for genetic improvement of grazing traits and further research is needed to identify the traits that could improve production and longevity on a high forage diet. Such research may also be a priority for intensive graziers and possibly for conventional producers if a long-term increase of energy costs will force a change toward more extensive milk production systems.

\section{ACKNOWLEDGMENTS}

The financial assistance from OntarBio, essential for this project, and the cooperation from CanWest DHI in Ontario in providing the milk recording data are kindly acknowledged. The authors also wish to thank the surveyed farmers for their time, patience, and cooperation and the personnel at OntarBio for their support and input on this research.

\section{REFERENCES}

Bapst, B. 2001. Swiss experience on practical cattle breeding strategies for organic dairy. Proc. 4th NAHWOA Workshop, Wageningen, The Netherlands. Network for Animal Health and Welfare in Organic Agriculture (NAHWOA), Univ. Reading, UK.

Baumung, R., J. Solkner, E. Gierzinger, and A. William. 2001. Ecological total merit index for an Austrian dual-purpose cattle breed.
Proc. 4th NAHWOA Workshop, Wageningen, the Netherlands. Network for Animal Health and Welfare in Organic Agriculture (NAHWOA), Univ. Reading, UK.

Bennedsgaard, T. W., S. M. Thamsborgb, M. Vaarst, and C. Enevoldsen. 2003. Eleven years of organic dairy production in Denmark: Herd health and production related to time of conversion and compared to conventional production. Livest. Prod. Sci. 80:121-131.

Boelling, D., A. F. Groen, P. Sorensen, P. Madsen, and J. Jensen. 2003. Genetic improvement of livestock for organic farming systems. Livest. Prod. Sci. 80:79-88.

Boettcher, P. J., J. Fatehi, and M. M. Schutz. 2003. Genotype $\times$ environment interactions in conventional versus pasture-based dairies in Canada. J. Dairy Sci. 86:383-389.

Canadian Dairy Network. 2003. Provincial race to superior genetics. http://www.cdn.ca/articles.php Accessed September 15, 2006.

Canadian Dairy Network. 2005. New Lifetime Profit Index starting February 2005. http://www.cdn.ca/articles.php Accessed July 15, 2006.

Canadian General Standards Board. 1999. The Canadian standards for organic agriculture. Document CAN/CGSB-32.310. http:// www.pwgsc.gc.ca/cgsb/on_the_net/organic/index-e.html Accessed July 15, 2006.

CanWest DHI. 2003. Provincial Statistics. http://www.canwestdhi.com/pdf_files/ 2003\%20provincial\%20statistics.pdf Accessed July $15,2006$.

Chesnais, J. P., and B. J. Van Doormaal. 2006. Forces of change. Presented at 'Endless Performance Visioning Conference', Ottawa, Canada. Canadian Livestock Genetics Assoc., Guelph, ON, Canada.

Dillon, P., F. Buckley, P. O'Connor, D. Hegarty, and M. Rath. 2003a. A comparison of different dairy cow breeds on a seasonal grassbased system of milk production. 1. Milk production, live weight, body condition score and DM intake. Livest. Prod. Sci. 83:21-33.

Dillon, P., S. Snijders, F. Buckley, B. Harris, P. O'Connor, and J. F. Mee. 2003b. A comparison of different dairy cow breeds on a seasonal grass-based system of milk production. 2. Reproduction and survival. Livest. Prod. Sci. 83:35-42.

Gamborg, C., and P. Sandøe. 2005. Sustainability in farm animal breeding: A review. Livest. Prod. Sci. 92:221-231.

Haas, E., and B. Bapst. 2004. Swiss organic dairy farmer survey: Which path for the organic dairy cow in the future? Pages 3541 in Proc. 2nd SAFO Workshop, Witzenhausen, Germany. M. Hori, A. Sundrum, and S. Padel, ed. Available at http://www. safonetwork.org/publications/ws2/index.html

Hardeng, F., and V. L. Edge. 2001. Mastitis, ketosis and milk fever in 31 organic and 93 conventional Norwegian dairy herds. J. Dairy Sci. 84:2673-2679.

Harris, B. L., and E. S. Kolver. 2001. Review of Holsteinization on intensive pastoral dairy farming in New Zealand. J. Dairy Sci. 84(E Suppl.):E56-E61.

Hollander, M., and D. A. Wolfe. 1973. Nonparametric Statistical Methods. John Wiley and Sons, New York, NY.

Interbull. 2006. Genetic evaluations. http://www-interbull.slu.se/ eval/framesida-genev.htm Accessed July 15, 2006.

Jorjani, H. 2005. Preliminary report of Interbull pilot study for female fertility traits in Holstein populations. Interbull Bull. 33:34-44.

Kearney, J. F., M. M. Schutz, P. J. Boettcher, and K. A. Weigel. 2004. Genotype by environment interaction for grazing versus confinement. I. Production traits. J. Dairy Sci. 87:501-509.

Kristensen, T., and S. S. Pedersen. 2001. Organic dairy cow feeding with emphasis on Danish conditions. Proc. 4th NAHWOA Workshop, Wageningen, the Netherlands. Network for Animal Health and Welfare in Organic Agriculture (NAHWOA), Univ. Reading, UK.

Krogmeier, D. 2003. Der Ökologische Gesamtzuchtwert für Fleckvieh, Braunvieh und Gelbvieh. [Biological total merit index for Simmental, Brown Swiss and Gelbvieh cattle]. Paper presented at Forschung für den ökologischen Landbau in Bayern, Ökolandbautag der LfL, Triesdorf, pages 77-86. Schriftenreihe der Bayerischen Landesanstalt für Landwirtschaft 3/03. Bayerische Landesanstalt für Landwirtschaft (LfL), Freising, Germany. 
Lopez-Villalobos, N., D. J. Garrick, C. W. Holmes, H. T. Blair, and R. J. Spelman. 2000. Profitabilities of some mating systems for dairy herds in New Zealand. J. Dairy Sci. 83:144-153.

Mark, T. 2004. Applied genetic evaluations for production and functional traits in dairy cattle. J. Dairy Sci. 87:2641-2652.

Miglior, F., B. L. Muir, and B. J. Van Doormaal. 2005. Selection indices in Holstein Cattle of various countries. J. Dairy Sci. 88:1255-1263.

Nauta, W. J. 2001. Breeding strategies for organic animal production, an international discussion. Proc. 4th NAHWOA Workshop, Wageningen, The Netherlands. Network for Animal Health and Welfare in Organic Agriculture (NAHWOA), Univ. Reading, UK.

Nauta, W. J., T. Baars, and H. Bovenhuis. 2006a. Converting to organic dairy farming: Consequences for production, somatic cell scores and calving interval of first parity Holstein cows. Livest. Prod. Sci. 99:185-195.

Nauta, W. J., R. F. Veerkamp, E. W. Brascamp, and H. Bovenhuis. 2006b. Genotype by environment interaction for milk production traits between organic and conventional dairy cattle production in the Netherlands. J. Dairy Sci. 89:2729-2737.
Offermann, F., and H. Nieberg. 2000. Economic performance of organic farms in Europe. Page 31 in Organic Farming in Europe: Economics and Policy, Vol. 5. University of Hohenheim, Stuttgart, Germany.

Olesen, I., A. F. Groen, and B. Gjerde. 2000. Definition of animal breeding goals for sustainable production systems. J. Anim. Sci. 78:570-582.

OMAFRA. 2003. Ontario Dairy Summary. www.gov.on.ca/OMAFRA/ english/busdvc/download/ondai03.htm Accessed July 15, 2006.

Pryce, J. E., E. E. Wall, A. B. Lawrence, and G. Simm. 2001. Breeding strategies for organic dairy cows. Proc. 4th NAHWOA Workshop, Wageningen, The Netherlands. Network for Animal Health and Welfare in Organic Agriculture (NAHWOA), Univ. Reading, UK.

Stonehouse, D. P., E. A. Clark, and Y. O. Ogini. 2001. Organic and conventional dairy farm comparisons in Ontario, Canada. Biol. Agric. Hort. 19:115-125.

VanRaden, P. M. 2004. Invited Review: Selection on net merit to improve lifetime profit. J. Dairy Sci. 87:3125-3131.

Weigel, K. A., R. Rekaya, N. R. Zwald, and W. F. Fikse. 2001. International genetic evaluation of dairy sires using a multiple-trait model with individual animal performance records. J. Dairy Sci. 84:2789-2795. 